\title{
У KINGS OF CHALDEA AND SONS OF NOBODIES: ASSYRIAN ENGAGEMENT WITH CHALDEA AND THE EMERGENCE OF CHALDEAN POWER IN BABYLONIA
}

\author{
John P. Nielsen \\ Bradley University
}

\begin{abstract}
From the ninth century until the last quarter of the seventh century BCE, the Assyrian Empire first extended its power over Babylonia and then engaged in a prolonged effort to retain control. The patchwork nature of Babylonian society-divided as it was between the traditional urban centers, territories controlled by five distinct Chaldean tribes, and regions inhabited by Aramaean tribes-presented opportunities and challenges for Assyria as it sought to assert its dominance. Assyrian interactions with the Chaldean tribes of Babylonia redefined the Chaldeans' place within power relationships in southern Mesopotamia. Starting in 878, Assyria first perceived Chaldean territory as distinct from what they defined as Karduniaš, the land ruled by the king of Babylon. Shalmaneser III exploited and accentuated this division by recognizing the Chaldean leaders as kings and accepting their tribute even as he concluded a treaty with the Babylonian king, Mardukzakir-shumi I. By decentralizing power in Babylonia, Assyria was able to assert indirect control over Babylonia. However, periods of Assyrian weakness created opportunities for several Chaldeansdrawing upon the economic and military power they could muster - to claim the title of king of Babylon with all the accompanying ideological power. These new developments prompted Assyria under the Sargonids to create counter-narratives that questioned the legitimacy of Chaldeans as kings of Babylon by presenting them as strange and inimical to the Assyrian order even as Assyrian interactions with the Chaldeans improved Assyrian familiarity with them.
\end{abstract}

In either the year 731 or $730 \mathrm{BCE}$, in the midst of Tiglath-pileser III's campaigns to unseat Mukīnzēri from the Babylonian throne, Aššr-šallimanni, the Assyrian governor of Arrapha, intercepted a message. It had been sent from Zākir, the head of the Chaldean tribe of Bīt-Ša'alli, to Merodachbaladan, his counterpart in Bīt-Yakīn (Luukko 2012: No. 87). In the letter, Zākir questioned Merodach-baladan's passivity in the face of Assyrian aggression, asking him: "Who do you think you are among the chieftains of Chaldea who are left for you? Why do you remain inactive (while) the Chaldean land is getting paralyzed?" Zākir went on to criticize another Chaldean chief, Balāssu of Bīt-Dakkūri, accusing him of giving the land of Chaldea over to destruction. This same Balāssu was present when the contents of the letter were read out before Aššur-šallimanni, and the governor's report to Tiglath-pileser related that Balāssu had become agitated upon hearing the letter's contents and asked that he be deported to Assyria at once. The reason for Balāssu's fear was that he was the maternal uncle of Mukīn-zēri, who in addition to being the king of Babylon was also the chief of the Chaldean tribe of Bìt-Amukāni. Balāssu was concerned that Mukīn-zēri

Volume 9(2) (2021), pp. 108-121

DOI $10.23993 /$ store. 89456

Licensed under Creative Commons 4.0 (CC BY-NC-SA 4.0) license.

ISSN: 2323-5209

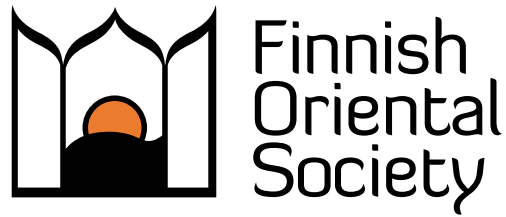


would bring the army and destroy the land, asking: "How can I become an enemy of my sister's son?" (Luukko 2012: xliii).

Aššur-šallimanni's report offers a rare emic perspective into the circles of Chaldean leadership and presents in a microcosm many of the factors that guided Assyrian interactions with the Chaldeans between the ninth and seventh centuries. The backdrop of the letter was Assyria's ongoing expansion fueled by its imperial ideology. The letter itself was generated by the apparatus that supported the empire, and it reflects Assyrian interests in the semi-autonomous Chaldean tribes, groups that had consistently figured into Assyrian efforts to dominate Babylonia. The fact that Mukinn-zēri was able to challenge Assyrian interests in Babylonia by being crowned king of Babylon is indicative of the powerful presence that the Chaldeans enjoyed within Babylonia. The threat that Assyria posed to the Chaldeans comes through in Zākir's statements. His anger at Chaldea's paralysis and concern that Chaldea would be destroyed indicate his ability to appeal to a shared Chaldean identity and territoriality when communicating with his fellow Chaldean leaders. In spite of this appeal, Merodach-baladan and Balāssu opted to side with Assyria in the conflict. These were not arbitrary decisions. Merodach-baladan was bound by treaty to Assyria (Luukko 2012: No. 133), another product of Assyria's imperial apparatus. Balāssu may have also faced the same restraints and thus elected to remain loyal to Assyria in spite of the kinship ties that both connected him to Mukinn-zēri as an uncle and cemented bonds of allegiance between the tribes of Bìt-Dakkūri to Bìt-Amukāni.

Ideology, empire, conquest, state, tribe, and kinship all intersected in the Assyrian encounter with the Chaldeans and played a role both in how Assyria defined the Chaldeans within the parameters of their empire. They also shaped how the Chaldeans responded to Assyrian pressure in Babylonia. Whereas the Chaldeans first appeared as strange to the Assyrians, Assyrian scribes quickly found familiar motifs within their imperial tradition with which to define them. However, as the Chaldeans emerged as an impediment to Assyrian domination in Babylonia, descriptions of the Chaldeans in Assyrian royal inscriptions, which had previously favored familiar Assyrian motifs used to portray a politically orderly and urbanized people, increasingly emphasized Chaldeans' disruptiveness and strangeness, even as epistolary evidence reveals that Assyrian familiarity with the Chaldeans improved over time.

These encounters were complicated by the Chaldean presence within Babylonia, a kingdom with which the Assyrians had a long history of relations, but which had undergone considerable change both after the collapse of the Kassite Dynasty and during the tumultuous first centuries of the first millennium. It was during this latter period that Assyria began to reengage with its southern neighbor as an ascendant imperial power. Simultaneously, the power held by the king of Babylon was waning and the prevailing trend in Babylonia between the tenth and eighth centuries was toward decentralization and fragmentation. As Assyria extended its empire into Babylonia, it sought to stabilize the region and combine the disparate urban and tribal identities that existed in southern Mesopotamia into a more manageable whole (Radner 2014: 104).

Given the political situation Assyria encountered in Babylonia, it is reasonable to consider how viable Babylonia was as a polity — both conceptually and practically_during these centuries and to what degree there was a shared Babylonian identity among the residents of the traditional urban centers of southern Mesopotamia. While a native term for Babylonia never existed, the venerable title "King of Sumer and Akkad," used first by the kings of the Ur III Dynasty, still had currency in the first millennium as an expression of the territorial expanse of the kingdom. The name Karduniaš, introduced during the Kassite Dynasty, also described Babylonia as a 
geographical entity (Soares 2017: 21-23). Furthermore, the title "King of Babylon" implied sovereignty beyond the city of Babylon. Though dated textual evidence from the tenth to eighth centuries is scarce, cities throughout southern Mesopotamia continued to follow the convention of dating texts by the regnal year of the "King of Babylon." Kings such as Nabû-apla-iddina, who withstood Assyrian expansion and patronized the cults at Sippar (Paulus 2014: 650-659) and Uruk (McEwan 1983), and Marduk-zākir-šumi I, whose treaty with Šamši-Adad V may have favored Babylonia (Brinkman 1968: 192-205) and who also patronized the priesthood at Uruk (Paulus 2014: 666-672), maintained a semblance of Babylonian strength and territorial cohesion throughout much of the ninth century. By the mid-eighth century, Nabonassar, whose hold on the Babylonian throne may have been reliant on Tiglath-pileser III's interventions against Arameans and Chaldean, was still acknowledged at Uruk with the title "King of Babylon" in a building inscription dated to his fifth regnal year (Frame 1995: B.6.15.2001). The residents of the traditional cult centers, referred to in Assyrian inscriptions as Akkadians, held a common sociocultural identity rooted in tradition that knit them together and differentiated them from Arameans and Chaldeans, even if their primary identification was with their respective cities (Brinkman 1984: 11; Frame 1992: 35-36; Cole 1996: 43-44; Nielsen 2018).

Within Babylonia, the five Chaldean tribes of Bīt-Dakkūri, Bīt-Amukāni, Bīt-Yakīn, Bīt-Silāni, and Bīt-Ša'alli controlled significant swathes of territory, stretching from Borsippa in the north to the region of the Sealand in the vicinity of Ur in the south (Beaulieu 2013a: 39-43). The Chaldeans in these regions interacted with the residents of Babylonia's traditional urban centers, and some Babylonian towns may even have been largely encompassed by Chaldean territory. These tribes enjoyed considerable autonomy from the king at Babylon, but as a midninth century kudurru dated to Marduk-zākir-šumi I's second year illustrates, they could also function as a constituent element subordinated to the king of Babylon. The kudurru records a grant of land and other property that had belonged to a Chaldean from the Bît-Amukāni tribe to an official from the Eanna temple at Uruk. It was witnessed at Babylon following the conclusion of the Akitu Festival by the crown prince, the ša rēši of the king, a man named IddinMarduk, son of Amukānu, the governor of Nippur, the bēl pīhāti, and a kalu-priest of Marduk (Paulus 2014: 669 Rs. iv 16-25). Given the status of the other witnesses, it is conceivable that Iddin-Marduk, who preceded the governor of Nippur in the list, was the head of the Chaldean tribe of Bīt-Amukāni, whose function it was to approve the transfer of property. His presence as a Chaldean at Babylon during a festival that renewed Marduk-zākir-šumi's kingship and marked the beginning of his second regnal year is indicative of the ideological weight that Chaldeans ascribed to the king of Babylon and explains the willingness of their leaders to take the title themselves.

The Assyrian encounter with the Chaldeans was conditioned by its own imperial project. As the first Iron Age empire to gain control over the entire Middle East, the Neo-Assyrian Empire exceeded in size and complexity the Late Bronze Age kingdoms that had divided control of the same region in the latter half of the second millennium. It was a multi-ethnic society in which its many subjects retained their distinct identities, even as an imperial identity was introduced. By the seventh century, deportations of non-Assyrians, settlements of Assyrian colonists, the adoption of Imperial Aramaic as a lingua franca, a unifying regime of provincial administration and taxation, and the establishment of borders delineating the "land of Aššur" ruled over by a semi-divine king all contributed to at least the partial Assyrianisation of the empire's many inhabitants (Machinist 1993; Parpola 2004: 7-22; Radner 2014: 106). Like world empires that 
would follow, the Assyrian Empire conceived of itself as the end of history, imposing a divinely mandated universal peace within its ever-expanding borders that distinguished between those who resided within and outside of the empire (Parpola 2004: 14). This ideology was expressed in royal inscriptions (Fales 1999-2001), imposed through conquest (Karlsson 2016: 147-158), and implemented by an elite cadre of Assyrian and Assyrianized officials who both administered provinces in accordance with the imperial vision and also parroted back its ideology in their reports (Radner 2015).

Centuries of Assyrian dominance built up a complex network of dependencies and relationships in which the identity of its participants played a critical role. The Assyrian identity of the conquerors defined the elite and was idealized (Fales 2018: 484-485). At the same time Assyrian power relied on the systemized exploitation of conquered peoples and territories (Liverani 1979; MacGinnis 2012: 147). The conquered experienced Assyrian power first through defeat and then through the identities imposed upon them by Assyria. Those populations, among whom were resettled deportees, could become "counted with the people of Assyria" as they became integrated into the empire, though that did not prevent them from being differentiated from true Assyrians from the perspective of the conquerors (MacGinnis 2012: 146). The portrayal of both ideal Assyrian subjects and the othering of groups viewed as inimical to imperial administration present within borders of the empire were essential topoi in royal inscriptions (Rosenzweig 2016: 310-314). From the top-down viewpoint of the Assyrian Empire, the resulting dichotomy differentiated urban residents from rural peoples, sedentary from nomadic, and agricultural from pastoral (Karlsson 2016: 200).

The Assyrian application of these categories, however, was not static: "Assyrian imperialism was a process, not an event, and it took place in a variety of contexts within differing exigencies" (Rosenzweig 2016: 314). Through expansion and consolidation, the Assyrian Empire was constantly negotiating how it defined territories and peoples. As a result, reality at the provincial level often differed from imperial ideology. This was true of Babylonia, where between the ninth and seventh centuries, Assyrian emperors initially propped up the monarchy at Babylon, but eventually asserted Assyrian control by either taking the throne for themselves or by appointing subjects or family members as vassals. However, by incorporating Babylonia into the empire, the Assyrians had to confront and understand Babylonia's fragmentary political landscape. Due to their historic relations with the Babylonian monarchy and longstanding appreciation of Babylonian culture and scholarship, Assyrian emperors understood and treated Babylon as the seat of royal power. However, for much of the tenth and ninth centuries, Babylonian kings had been relatively weak and had even resided and maintained their courts at cities other than Babylon (Brinkman 1968: 294). With royal influence diminished at Babylon, the traditional urban cult centers of Babylonia, from Sippar in the north to Ur in the south, were able to exercise a limited degree of autonomy from the crown. Furthermore, Aramean and Chaldean tribal groups who occupied significant stretches of territory throughout southern Mesopotamia were largely beyond royal authority. The Chaldeans, in particular, would prove problematic to Assyrian rule, wresting the Babylonian throne away on several occasions and making Babylonia one of the most challenging provinces to govern (Frame 2008).

The Chaldeans' first appearance in the historical record occurs in sources generated in Assyria. These texts reflect the limited etic perspective that the Assyrians had as they began to reengage with Babylonia in the early ninth century. Following the Assyrian defeat of the land of Suhu on the Middle Euphrates in 878, Ashurnasirpal II claimed in his royal inscrip- 
tions that "fear of [his] dominion extended to Karduniaš (i.e., Babylonia) [and] that awe of [his] weapons overwhelmed Chaldea" (Grayson 1991: A.0.101.1 iii 23-24). His inscriptions, however, refer to Babylonia as Karduniaš, a name that had been introduced under the Kassites several centuries earlier, but which had fallen out of use in Babylonia (Brinkman 1980: 423). The army sent by the Babylonian king, Nabû-apla-iddina, to assist in the defense of Suhu were called Kassite troops in the Assyrian inscriptions (Grayson 1991: A.0.101.1 iii 17). The use of these designations was probably intentionally anachronistic; Assyrian inscriptions continued to use Karduniaš for Babylonia in the latter part of the seventh century. In the early ninth century, however, their use may also betray a lack of Assyrian familiarity with the contemporary situation in Babylonia, necessitating a reliance on more traditional terms. The Assyrians knew even less about Chaldea. Like Babylonia, Chaldea was described as a "land" (kur/mātu), and not simply as a people, indicating that the Assyrians conceived of it as a distinct territorial entity located beyond Babylonia.

Assyrian familiarity with the Chaldeans improved during the reign of Shalmaneser III, who increased Assyrian involvement in Babylonia after concluding a peace treaty with Nabû-aplaiddina (Glassner 2004: 182-183). When Nabû-apla-iddina's son, Marduk-zākir-šumi I, was confronted with a rebellion in 851 , Shalmaneser intervened and helped quell the uprising the following year. However, having restored the status quo at Babylon, Shalmaneser did not opt to return to Assyria but instead made offerings at the major shrines in Babylon, Borsippa, and Cutha. He then launched a series of military offensives into Chaldean territory, first capturing and destroying the city of Baqānu in the territory of Bīt-Dakkūri, and then besieging the royal city of Huradu and compelling Bīt-Dakkūri's ruler, Adinu, to surrender and offer tribute. With Bīt-Dakkūri defeated, the Chaldean chiefs of Bīt-Yakīn and Bīt-Amukāni sent tribute to Shalmaneser as an act of submission (Grayson 1996: A.0.102.5 v 3b-vi7).

Already in Shalmaneser's inscriptions, it is clear that the Assyrians categorized the Chaldeans as a sedentarized and urbanized population who dwelled in walled cities and towns, but who were not Babylonians. They had identifiable rulers who were acknowledged with the title of king in some of Shalmaneser's inscriptions and who resided in royal cities (Grayson 1996: A.0.102.59:47). These identities shaped how Shalmaneser classified the Chaldeans as a settled and therefore governable population within the framework of the empire. Furthermore, Shalmaneser styled himself as a champion of Babylon in his defeat of the Chaldeans, having vanquished Bīt-Dakkūri with "the fearful splendor of Marduk" after making offerings at Babylon to the city's patron deity, Marduk (Grayson 1996: A.0.102.5 vi 7). By performing these rites, Shalmaneser was portraying himself as an agent of Marduk, associating himself with Babylon, and inserting himself into power relationships within Babylonia. Marduk-zākir-šumi I may have been king of Babylon, but his hold on the throne relied on Shalmaneser's support; he was functionally, if not formally, a vassal of Shalmaneser, whose actions had appropriated Babylonian royal prerogatives. From the Assyrian perspective, classifying the Chaldeans as tributaries imposed upon them a familiar subordinate identity that had antecedents in Middle Assyrian imperial ideology (Karlsson 2017: 72, 88). It must also have had implications for how Shalmaneser understood his relationship with Marduk-zākir-šumi. By receiving tribute from the Chaldean kings, Shalmaneser both recognized their status as local rulers and established a relationship with them in which they were subordinated to Babylon through his actions on behalf of Marduk and subject to him as vassals, further diminishing Marduk-zākir-šumi's status in the process. 
The inscriptions of Ashurnasirpal II and Shalmaneser III also make it clear that the Chaldeans had an established presence in Babylonia by the ninth century. Babylonian evidence is sparse for the early first millennium, but there is no earlier mention of the Chaldeans in the Babylonian sources that do survive. When the Chaldeans first appeared in southern Mesopotamia is unknown, but it is plausible that they arrived among the population movements spearheaded by the Arameans that began at the end of the twelfth century. These migrations caused significant disruptions throughout Mesopotamia that were vividly described in both contemporary and later Assyrian and Babylonian sources into the tenth century. While it is clear that the Chaldeans possessed their own distinct identity by the ninth century, a shared heritage with the Arameans can be postulated from onomastic evidence, which indicates that the Chaldeans, like the Arameans, spoke a West Semitic dialect. Furthermore, the Chaldean practice of identifying collectively as members of a tribal house named for an eponymous ancestor resembled identities utilized in Aramean kingdoms in the Jezirah and Transeuphratene (Fales 2011: 95).

If the Chaldeans' antecedents in Babylonia were part of greater population movements that spanned the late second and early first millennia, it is notable that Assyrians and Babylonians alike distinguished the Chaldeans from the Arameans. In both Assyrian and Babylonian traditions, the Arameans were stigmatized as a destructive force who seized territory, sacked cities, and looted temples. From 1114 to 1076, Tiglath-pileser I directed twenty-eight campaigns against encroaching Arameans (Grayson 1991: A.0.87.4:34-36). Nearly a century later, Assyrian emperors, starting with Aššur-dān II, had to campaign to recapture territory that had been lost to the Arameans (Grayson 1991: A.0.98). In Babylonia, the sun god Tablet of Nabû-apla-iddina, composed in the mid-ninth century, relates how the Arameans had sacked Sippar two centuries earlier, destroying the statue of Šamaš and putting a stop to proper observation of the cult (Paulus 2014: 644-646), and an inscription set up by Simbar-Šipak in the last quarter of the eleventh century that described how the Arameans had looted the throne of Enlil from Nippur was still being copied four centuries later (Frame 1995: B.3.1.1). These and other attacks on cult centers were commemorated in the Babylonian chronicles as well as on several occasions when Aramean tribes in the countryside prevented the proper celebration of the Akitu Festival at Babylon in the first half of the tenth century (Glassner 2004: 300-301). Compared to the Chaldeans, Aramean tribes in Babylonia retained a more pastoral and semisedentary lifestyle, and their tribal and family units displayed greater interregional and social mobility, leading to more fluid membership, a higher degree of tribal segmentation, and less centralized leadership (Fales 2011: 94).

Shalmanesser III's son, Šamšī-Adad V (Glassner 2004: 182-183), and grandson, Adadnērārī III (Grayson 1996: A.0.104.8:22-24), continued to recognize the Chaldeans as Assyrian vassals and acknowledged Babylonia's autonomy while simultaneously bringing Babylonia within its sphere of influence (Beaulieu 2013b: 9). Having ascended to the Assyrian throne in 823, Šamš̄-Adad V was reliant on Babylonian aid to withstand a revolt led by his brother. The treaty he concluded with Marduk-zākir-šumi I may have been unfavorable to Assyria, but in 814 , Šamš̄i-Adad launched the first of four successive campaigns against Babylonia that shifted the balance of power back to Assyria. Emulating his father, Šamš̄i-Adad appropriated the prerogatives of Babylonian kingship by performing sacrifices at Cutha, Babylon, and Borsippa and then marched into Chaldean territory where he received tribute from Chaldean leaders. Adad-nērārī III pursued a similar tack in Babylonia to his father, but Assyrian weakness coupled with an interregnum in Babylonia created conditions that would alter Assyria's involve- 
ment in Babylonia and its relationship with the Chaldeans: the assumption of the Babylonian throne by a series of Chaldean kings (Brinkman 1968: 192-220).

Three Chaldeans-Marduk-apla-ușur, Erība-Marduk, and Nabû-šuma-iškun-occupied the Babylonian throne consecutively over the course of the first half of the eighth century. Furthermore, during the latter half of the eighth and the early part of the seventh centuries, three more Chaldeans occupied the throne: [Nabû]-mukīn-zēri (731-729), Merodach-baladan II (721-710, 703), and Mušēzib-Marduk (692-689). The major Chaldean tribes of Bīt-Amukāni, Bīt-Dakkūri, and Bìt-Yakīn were all represented among these kings, and it is likely that all six were from the ruling families within their respective tribes. The acceptance and success some of these kings enjoyed on the Babylonian throne suggests that from the Babylonian perspective, a Chaldean king was tolerable and not automatically viewed as an interloper. The Chaldeans were a distinct but familiar part of the patchwork that was Babylonia and were enmeshed-politically, economically, and militarily — with the Babylonian population. Politically, the Chaldean kings sought the favor of the urban population by adopting Babylonian royal titles, participating in royal rites such as the Akitu Festival, and tending to the maintenance of local cults and the upkeep of their temples. Merodach-baladan II's building inscription commemorating his restoration work on the Eanna at Uruk epitomizes this attempt to shape a Babylonian identity for himself as king (Frame 1995: B.6.21.1). In it, he was presented as fulfilling the tradition of local kingship, hearkening back more than a thousand years to the Ur III ruler Šulgi, whom Merodach-baladan claimed had built the Eanna. He also claimed that Marduk had chosen him for kingship after having been angry with Babylonia for the previous seven years of Assyrian rule. Finally, he emphasized his descent from Erība-Marduk, the second Chaldean king of Babylonia, whose rule had ended approximately four decades before Merodach-baladan had claimed the throne.

Erība-Marduk appears to have also adopted policies favoring the urban Babylonians. More than two centuries after his reign ended, chroniclers at Borsippa approvingly recalled that Erība-Marduk had rid the countryside around Babylon and Borsippa of the Aramean tribes that had seized fields from the cities' inhabitants, and returned them to the citizens (Glassner 2004: 286-287). Merodach-baladan imitated Erība-Marduk's earlier actions when he oversaw a land grant in which he presented agricultural land to the privileged citizens of Babylon and Borsippa and other Babylonian cult centers that had been stolen previously by people he called "hostile foreigners" (Paulus 2014: 695-696). If Erība-Marduk's restoration of land recalled the trope of Arameans as nomads hostile to urban civilization that was familiar to Assyrians and Babylonians alike, then it is possible that Merodach-baladan II was using the vagaries of the term "hostile foreigners" to conflate Arameans with the Assyrians in order to remind his urban Babylonian audience that both Arameans and Assyrians had a history of destructive invasions in Babylonia, while the Chaldeans had no such reputation and would uphold historical norms that privileged the landed urban elite.

Economically and administratively, the Chaldeans both introduced important innovations throughout Babylonia and integrated themselves into the existing frameworks. Erība-Marduk and Merodach-baladan's land distributions benefited urban Babylonians and were intended to stabilize the agrarian base of the urban economy. Their efforts appear to have been the foundation of the land-for-service hanš̂u-system that would also be co-opted and implemented by non-Chaldean kings. The hanšû-fields that were created remained prevalent in cities throughout Babylonia until their replacement by the Persians (Nielsen \& Waerzeggers 2016: 333-335). These acts cultivated a positive assessment of these kings' reigns in the memories of a segment of the urban population; 
sales of hanšŝ-fields concluded as much as a century after the grants took place still described the land as being located in the divisions of Erība-Marduk and Merodach-baladan II, respectively (Nielsen 2010: 98 2b lns. 2-3; Nielsen \& Waerzeggers 2016: 341 n. 5). Furthermore, when a nonChaldean king held the Babylonian throne, Chaldean leadership could still be drawn into the administrative apparatus. When Šamaš-šuma-ukīn, who was the son of Esarhaddon, granted possession of two estates located in the territory of Bīt-Dakkūri, Nabû-ušallim, the head of Bīt-Dakkūri was present among other Babylonian officials to certify the act (Paulus 2014: 735). Finally, at the local level there are also indications that the Chaldeans were integrated into economic networks and the administrative practices that governed them. A sale of a ruined house at Uruk concluded in 673 at the Chaldean town of Šapiya in Bīt-Amukāni had as its first witness Ea-zēra-iqī̌ša, the ruler of Bìt-Amukāni (Frame 2013: No. 4: 31). His presence at the head of the list mirrored administrative practices at the nearby city of Uruk and elsewhere where the šăkin-témi typically acted as the first witness to land sales.

The Chaldeans likely played an important role in long-distance trade routes that stretched beyond Babylonia to the Iranian plateau, the Persian Gulf, Arabia, and the Levant. Assyrian lists of the tribute presented by Chaldean kings to campaigning Assyrian emperors hint at the amount and diversity of wealth that the Chaldeans could accumulate (Brinkman 1984: 42-43; Cole 1996: 20-21). The competition that this southern axis of trade posed to networks that passed through the Assyrian heartland may have contributed to the Assyrian desire to invade Chaldean territory (Fales 2011: 97). The major Babylonian urban centers may not have controlled these trade routes, but urban entrepreneurs would have been integrated into these networks. As a result, the cities would have been important participants, resulting in the generation of tablets documenting harrānu-ventures that occasionally feature men with Northwest Semitic names or patronyms that may reveal their Chaldean identities (Spar \& Von Dassow 2000: No. 6: 9-11; Jursa 2005: 72).

Finally, the Chaldeans were integrated into Babylonia as a constituent part of a broader Babylonian defense under both Chaldean and non-Chaldean kings of Babylon. Assyrian pressure on Babylonia drew Chaldeans into Marduk-balāssu-iqbi's efforts to repulse Assyrian invasions. Šamš̄i-Adad V's first foray into Babylonia was checked at Dūr-Papsukkal near Der in 814 by a Babylonian-led coalition that included Chaldean troops fighting alongside Elamites, Arameans, and soldiers from Namri in the Zagros (Grayson 1996: A.0.103.1 iv 37-45). Chaldean kings such as Mukīn-zēri and Merodach-baladan II were also able to draw upon the support of Babylonian cities in the face of Assyrian invasions. Mukīn-zēri had only limited success in maintaining the loyalty of both his Babylonian subjects and his fellow Chaldeans; Tiglathpileser III either retained their loyalty or pried them away from Mukīn-zēri through diplomacy and military pressure (Brinkman 1984: 42-43). Loyalty among Chaldeans to Tiglath-pileser III may account for the chariotry unit comprised of Chaldeans named in the Nimrud Horse Lists in the service of Sargon II (Dezső 2012: 83). By contrast, Merodach-baladan II, whose tenure on the throne was much longer than that of Mukīn-zēri, was more effective than his predecessor in currying the support of urban Babylonians. Their loyalty disintegrated in the face of Sargon II's campaign of 710, but when Merodach-baladan retook the throne in 703, he was able to recruit urban Babylonians in the failed effort to withstand Sennacherib's invasion (Brinkman 1984: 49-53, 56-59). Chaldeans also supported Šamaš-šuma-ukīn's revolt against Ashurbanipal between 652 and 648. Constituents from Bīt-Dakkūri and Bìt-Amukāni probably joined the rebellion even though Ashurbanipal's efforts neutralized the full participation of these tribes. Nabû-bēl-šumāti, a descendant of Merodach-baladan II, led Bīt-Yakīn's revolt against Assyria 
from the Sealand. He joined with Šamaš-šuma-ukīn in opposition to Ashurbanipal, but it is unclear if there was coordination between Šamaš-šuma-ukīn in the north and Nabû-bēl-šumāti in the south. It is therefore an open question if Nabû-bēl-šumāti was motivated by self-interest, given his own claim to royal ancestry; had the Assyrian yoke been thrown off, he may have become Šamaš-šuma-ukīn's rival (Frame 1992: 170-182). However, Chaldean participation in the Babylonian military was not simply a product of resistance to Assyrian aggression. After the fall of the Neo-Assyrian Empire, Chaldean tribal levies contributed to the Babylonian army that created and maintained the Neo-Babylonian Empire, retaining a distinct identity from other groups that traditionally supplied troops (MacGinnis 2010: 160).

As a sedentary population, the Chaldeans were integrated into the social, economic, and political networks linking cities and settled agrarian regions throughout Babylonia. However, just as rivalries between different Babylonian cities could spill over into violence, the Chaldeans did not always coexist peacefully with their Babylonian neighbors. Likewise, Chaldean kings of Babylon did not consistently receive the full support of their Babylonian subjects. In these instances, Chaldean identity may have become accentuated in the eyes of the Babylonians. The most dramatic conflict to entangle Babylonians and Chaldeans was described by Nabû-šumaimbi, the governor of Borsippa during the reign of the Dakkūrian, Nabû-šuma-iškun in the mideighth century. In a foundation deposit that emulated a royal inscription in form and content, Nabû-šuma-imbi recounted how the inhabitants of Babylon, Borsippa, all the Chaldeans and Arameans, and the people of Dilbat did battle against one another (Frame 1995: B.6.14.2001 i $15^{\prime}$ 'b-21'). Disputes over fields seem to have been at the heart of this conflict and may have been a source of tension between urban Babylonians and the Chaldeans of Bīt-Dakkūri. As has already been discussed, the earlier removal of Arameans from these lands by the previous Chaldean king, Erība-Marduk, was held up for praise by Babylonian chroniclers. In this vein, Esarhaddon would later claim that he removed the Chaldeans of Bīt-Dakkūri. In addition to territorial disputes, the Babylonian reactions to Chaldean kings were not exclusively positive. Both at the time of their reigns and in historical memory, anti-Chaldean sentiments were present. Assyrian claims that the Babylonian priesthood invited Assyrians to assume the Babylonian throne find support in letters sent from pro-Assyrian elements in Babylon (Dietrich 2003: Nos. 20-23). Chaldean kings were also portrayed as foreign by the Babylonians. A Late Babylonian chronographic literary text from Uruk recounts that Nabû-šuma-iškun showed favor to Chaldeans and Arameans, murdered and mistreated Babylonians, committed blasphemies, and introduced foreign gods (Cole 1994; Beaulieu 2001; Zadok 2017). In the Uruk Prophecy, a text also known from Late Babylonian Uruk, Erība-Marduk (Beaulieu 1993), or more likely his successor, Nabû-šuma-iškun (Beaulieu 2001), was remembered as having removed the cultstatue from Uruk, which he replaced with a foreign idol. When it suited Babylonian purposes, Chaldeans could be presented as alien. The Assyrians exploited and cultivated this capacity.

Assyria responded to Chaldean kings on the Babylonian throne with its formidable army, against which even the most dogged Chaldean resistance ultimately failed. Every Assyrian invasion was also accompanied by Assyrian efforts to win the hearts and minds of the urban Babylonians and to draw lines of distinction between Babylonians and Chaldeans. The primary purpose of these efforts was to undermine Babylonian support for Chaldean kings, but they also reflected a change in how Assyria perceived Chaldean identity in relationship to Babylonia. Whereas Ashurnasirpal II's inscription had envisioned a land of Babylonia and a land of Chaldea beyond it, and Shalmaneser III had recognized Chaldean rulers as vassal kings, increasing 
Assyrian involvement in Babylonia, some of which was in response to Chaldeans seizing the Babylonian throne, led subsequent Assyrian emperors to appreciate Babylonia as an agglomerated polity that was ruled from Babylon and which encompassed many disparate urban and tribal regions (Nielsen 2018). Chaldean rulers had provided a useful counterbalance to the power of those native Babylonian kings over whom Assyria exerted hegemony, but Chaldeans could not be tolerated as independent kings of Babylon. Beginning with Tiglath-pileser III in 731 (Luukko 2012: xxxi-xxxii), Assyrian emperors opted to take the Babylonian crown for themselves or appoint others, including members of the Assyrian royal family, as king of Babylon.

Over multiple conflicts, Assyrian emperors regarded their Chaldean counterparts on the Babylonian throne with a mixture of disdain and hostility, and these attitudes shaped Assyrian perceptions of the Chaldeans. In Tiglath-pileser III's inscriptions, Mukīn-zēri's legitimacy as king of Bīt-Amukāni is unquestioned, but his status as king of Babylon is never acknowledged (Tadmor \& Yamada 2011: No. 51: 16). Furthermore, reports sent to the king detailing Mukīn-zēri's activities do not describe him with pejorative language (Luukko 2012: 257). By comparison, much more animosity was reserved for Merodach-baladan. Sargon II's accounts of his campaigns against Merodach-baladan acknowledge his opponent as king of Chaldea but claimed that his kingship over Babylon was not sanctioned by the gods. From the perspective of Assyrian imperial ideology, Merodach-baladan had committed additional blasphemies by not sending tribute in violation of the vassal treaty that he had concluded with Assyria when he had been an ally in the war against Mukīn-zēri. Furthermore, the landscape in which he resided, while not the wild steppes inhabited by the Arameans, was a marsh shaped by the floods and the waters of the deep (Bagg 2020; Grayson \& Novotny 2012: No. 1: 34, No. 16 iv 56-61, 34: 7-11 and passim). Reliefs from the Southwest Palace at Nineveh depicting the Babylonian terrain in which Sennacherib and his successors campaigned added to this impression, presenting the primordial strangeness of the marshes of the Sealand in contrast with the orderly bounty of urbanized Babylonia with its rows of fruit-bearing date palms (Seymour 2017: 134-139, 141-158).

The wickedness of Merodach-baladan and the Chaldeans is further accentuated in Sennacherib's inscriptions, which stress that it was Merodach-baladan, having regained the throne at Babylon in 703, who undermined the peace and obedience that had prevailed at Sennacherib's accession. By listing the Chaldeans, Elamites, Arameans, and Babylonians that Merodach-baladan arrayed against Assyria, Sennacherib was giving tacit admission to his rival's diplomatic skills but also fulfilling the motif of the emperor who defeats chaos (Grayson \& Novotny 2012: No. 1: 4-15). Merodach-baladan's flight after his defeat to his homeland in the swamps of Bît-Yakīn and ability to elude capture and find his way to Elam was a further reminder that the Chaldeans of Bît-Yakīn occupied an alien landscape in Assyrian eyes and were not truly sedentarized imperial subjects (Grayson \& Novotny 2012: No. 15 iv 24'-v 2a). When Sennacherib's scribes characterized Mušēzib-Marduk, the last Chaldean to occupy the Babylonian throne in defiance of Assyria, as mār la mammanama 'the son of a nobody,' a designation reserved for upstarts and usurpers, Chaldean identity as it was construed by the Assyrians reached a nadir (Grayson \& Novotny 2014: No 147 obv. 6). Whereas Chaldea had once been identified as a land ruled by tribute-bearing vassal kings, it had become a wilderness whose rulers lacked legitimacy. 
Assyrian involvement in Babylonia had a galvanizing effect on the Chaldeans. This is most evident in the decision of six Chaldean kings to assume the Babylonian throne and organize resistance to Assyrian expansion, but it may also have shaped a shared Chaldean identity. These kings frequently encountered difficulty in unifying all five Chaldean tribes against Assyrian invasions. However, the pressure the Assyrians placed on the Chaldeans kings may have cultivated a sense of common political identity among the Chaldean tribes that strengthened their shared social identity. The aforementioned report from Aššur-šallimanni indicates that at least among the Chaldean elite, intermarriage between the different tribes occurred. These relationships created strategic bonds of kinship, which, judging by Balāssu's fear of a military reprisal from Mukīn-zēri, brought with them obligations of mutual support and allegiance that would have superseded any oaths sworn to Assyria. Yet, appeals to a shared Chaldean identity expressed in the report suggest that even when Mukīn-zēri occupied the Babylonian throne, the leading figures among the Chaldeans recognized Chaldean tribal territory as a geographic entity with its own interests.

Sennacherib's removal of Mušēzib-Marduk during the Assyrian sack of Babylon in 689 marked the last time an identifiable Chaldean held the Babylonian throne. After Sennacherib's assassination, Esarhaddon's rebuilding and resettlement of Babylon signaled an Assyrian desire to restore its relationship with Babylonia. Ubāru, Esarhaddon's appointee as governor of Babylon, was perhaps appealing to Esarhaddon's ambitions for harmonious relations with both his Babylonian and Chaldean subjects in a report he sent back to Assyria after he had arrived in Babylon. The people of Babylon, he claimed, blessed Esarhaddon as "the one who returned Babylon's captives and booty," and "the chiefs of Chaldea from Sippar to the mouth of the sea" blessed him as "the one who resettled Babylon" (Reynolds 2003: No. 14). Ubāru portrayed Babylonians and Chaldeans as parallel groups existing under the aegis of Assyrian power projected from Babylon and at the same time he acknowledged the extent of Chaldean territory within Babylonia. However, a very different characterization of the Chaldeans appears in Esarhaddon's royal inscriptions, which claim that Esarhaddon returned fields to the people of Babylon and Borsippa that had been stolen by the Chaldeans of Bīt-Dakkūri (Leichty 2011: No. 1 iii 62-70). Esarhaddon's action utilized the trope of the restoring king, familiar from the Babylonian Chronicle's description of Erība-Marduk's return of land stolen by the Arameans and Merodach-baladan II's inscription in which he returned land lost during Assyrian rule. The description of Bît-Dakkūri's king Šamaš-ibni as a rogue and outlaw reinforced the perception of Chaldeans as a chaotic element that threatened imperial stability.

The royal correspondence from Esarhaddon's and Ashurbanipal's reigns shows matters in Babylonia and relations with the Chaldean tribes to have been more complex than what was presented in the Assyrian royal inscriptions. The Chaldeans appear in letters as one of many constituencies that had to be balanced against others and managed in order for Assyria to govern Babylonia. The Chaldean response to the Šamaš-šuma-ukin revolt epitomizes this reality. Whereas Ashurbanipal claimed in his annals that Šamaš-šuma-ukin incited the Chaldeans to revolt, it was only Bīt-Yakīn, led by Merodach-baladan's descendant Nabû-bēl-šumāti, that rose up in its entirety. By contrast, elements within Bīt-Dakkūri and Bīt-Amukāni participated in the revolt, but a combination of Assyrian diplomacy and pressure - including taking hostages - kept both tribes in check (Frame 1992: 170-182). A similar division was present among the urban Babylonian population. Šamaš-šuma-ukīn had the support of Babylon, Borsippa, and Dilbat, but cities such as Nippur and Uruk sided with Assyria (Frame 1992: 137-167). In this regard, Chaldean involvement in the Šamaš-šuma-ukīn revolt resembled the support they gave to Mukīn-zēri nearly a century earlier. Tiglath-pileser was able to retain the loyalty of Bīt-Yakīn and Bīt-Dakkūri while prying away the 
support of Babylonian cities. Likewise, the complex network of Chaldean and Aramean tribes and Babylonian urban centers of the eighth century as revealed in the letter archive from Nippur (Cole 1996: 23-44) resembles those which Ashurbanipal confronted as he sought to defeat the uprisings of Šamaš-šuma-ukīn and Bìt-Yakīn.

The degree to which the Chaldeans were a distinct yet integral part of Babylonia becomes apparent with the disappearance of the Assyrian Empire's etic perspective from the historical record. While the term "Chaldean" is absent from Neo-Babylonian sources that postdate the collapse of the Assyrian Empire, the Hofkalender of Nebuchadnezzar II demonstrates that the Chaldeans remained an integral part of Babylonian society: the leaders of Bīt-Amūkāni and Bīt-Dakkūri and possibly Bīt-Yakīn — called the Sealand in the text—were important figures in the Neo-Babylonian court. Furthermore, tablets from the Eanna archive from Uruk reference individuals who possessed Chaldean tribal identity or resided in those geographic territories (Beaulieu 2013a: 33-37). Even the dynasty that Nabopolassar inaugurated, though only designated as Chaldean by later Biblical and Classical writers, may have had Chaldean origins. While Jursa has raised the possibility that Nabopolassar was the son of Kudurru, who had been governor of Uruk under Ashurbanipal (Jursa 2007), he has also suggested that a Neo-Babylonian letter from Sippar alludes to Nabopolassar as "the Dakkūrean" (Jursa 2006: 161 n. 8).

While the extent to which the dynasty founded by Nabopolassar possessed a Chaldean identity remains unknowable, its success in incorporating Chaldeans into the Babylonian imperial project differed markedly from Assyria's experience. Assyria first used Chaldean leaders as a counterbalance to a subordinated Babylonian king. When the Babylonian monarchy collapsed and Chaldeans seized the Babylonian throne, Assyria was faced with kings who ruled with minimal opposition within Babylonia. The etic perspective of Assyrian ideology was limited in how it could categorize the Chaldeans. The initial Assyrian encounter with the Chaldeans placed them in the familiar category of minor kings ruling over sedentary populations, and Assyrian campaigns soon transformed the Chaldeans into tribute-owing vassals of the empire. As the Chaldeans began to compete with the Assyrians for control in Babylonia, the Assyrians shifted the Chaldeans from the familiar - a sedentary and urban people ruled by kings - to an ungovernable strange that inhabited swamps and threatened the imperial order imposed by Assyria. At no time did Assyrian ideology appreciate the Chaldeans as a distinct but constituent part of the broader and more complex Babylonian polity. However, Assyria's diplomatic engagement within Babylonia, including with the Chaldeans, led to a familiarity with the complex divisions across Babylonia's urban centers and tribal regions. These lines routinely shifted, and it was in the empire's interest that it be apprised of developments in Babylonia. Assyrian efforts seem to have used this knowledge to keep at least a segment of the Chaldean population loyal or at least in check. This required diplomacy and coercion that could only be achieved through familiarity, even as Assyrian ideology increasingly portrayed the Chaldeans as strange.

\section{REFERENCES}

BAGG, Ariel M. 2020. The Unconquerable Country: The Babylonian Marshes in the Neo-Assyrian Sources. Water History 12: 57-73.

Beaulieu, Paul-Alain 1993. The Historical Background of the Uruk Prophecy. In: M. Cohen, D.C. Snell, D.B. Weisberg \& W.W. Hallo (eds), The Tablet and the Scroll: Near Eastern Studies in Honor of William W. Hallo: 41-52. Bethesda, MD: CDL Press. 
BeAulieu, Paul-Alain 2001. The Abduction of Ištar from the Eanna Temple: The Changing Memories of an Event. In: T. Abusch, P.-A. Beaulieu, J. Huehnergard, P. Machinist, P. Steinkeller \& C. Noyes (eds), Proceedings of the XLVe Rencontre Assyriologique Internationale, I: Historiography in the Cuneiform World: 29-40. Bethesda, MD: CDL Press.

Beaulieu, Paul-Alain 2013a. Arameans, Chaldeans, and Arabs in Cuneiform Sources from the Late Babylonian Period. In: A. Berlejung \& M.P. Streck (eds), Armaeans, Chaldaeans, and Arabs in Babylonia and Palestine in the First Millennium B.C. (Leipziger Altorientalische Studien 3): 31-55. Wiesbaden: Harrassowitz.

Beaulieu, Paul-Alain 2013b. Up for Grabs: Babylonian Kingship during the Iron Age. The Canadian Society for Mesopotamian Studies Journal 8: 5-15.

Brinkman, J.A. 1968. A Political History of Post-Kassite Babylonia, 1158-722 BC. (Analecta Orientalia 43) Rome: Pontificum Institutum Biblicum.

Brinkman, J.A. 1980. Karduniaš. In: D.O. EdzArd (ed.), Reallexikon der Assyriologie 5: 423. Berlin: De Gruyter.

Brinkman, J.A. 1984. Prelude to Empire, Babylonian Society and Politics, 747-626 BC. Philadelphia: Occasional Publications of the Babylonian Fund.

Cole, Steven W. 1994. The Crimes and Sacrileges of Nabû-šuma-iškun. Zeitschrift für Assyriologie 84: 220-252.

Cole, Steven W. 1996. Nippur in Late Assyrian Times, c. 755-612 BC. (State Archives of Assyria Studies 4) Helsinki: The Neo-Assyrian Text Corpus Project.

Dezsö, Tamás 2012. The Assyrian Army I. The Structure of the Neo-Assyrian Army as Reconstructed from the Assyrian Palace Reliefs and Cuneiform Sources, II: Cavalry and Chariotry. (Antiqua et Orientalia 3) Budapest: Eötvös University Press.

Dietrich, Manfried 2003. The Babylonian Correspondence of Sargon and Sennacherib. (State Archives of Assyria 17) Helsinki: Helsinki University Press.

FALES, Mario 1999-2001. Assyrian Royal Inscriptions: Newer Horizons. State Archives of Assyria Bulletin 13: 115-144.

FALES, Mario 2011. Moving around Babylon: On the Aramean and Chaldean Presence in Southern Mesopotamia. In: E. Cancik-Kirschbaum, M. van Ess \& J. Marzahn (eds), Babylon: Wissenkultur in Orient und Okzident: 91-111. Berlin: De Gruyter.

Fales, Mario 2018. The Composition and Structure of the Neo-Assyrian Empire: Ethnicity, Language and Identities. In: S. Fink \& R. Rollinger (eds), Conceptualizing Past, Present and Future. Proceedings of the Ninth Symposium of the Melammu Project Held in Helsinki / Tartu May 18-24, 2015: 443-494. Münster: Ugarit.

Frame, Grant 1992. Babylonia 689-627 B.C.: A Political History. (Publications de l'Institut historique-archéologie néerlandais de Stamboul 69) Leiden: Nederlands Historisch-Archaeologish Instituut in het Nabije Oosten.

FRAME, Grant 1995. Rulers of Babylonia from the Second Dynasty of Isin to the End of Assyrian Domination (1157612 BC). (Royal Inscriptions of Mesopotamia Babylonian Periods 2) Toronto: University of Toronto Press.

Frame, Grant 2008. Babylon: Assyria's Problem and Assyria's Prize. The Canadian Society for Mesopotamian Studies Journal 3: 21-31.

Frame, Grant 2013. The Archive of Mušēzib-Marduk, Son of Kiribtu and Descendant of Sìn-nāșir: A Landowner and Property Developer at Uruk in the Seventh Century BC. (Babylonische Archive 5) Dresden: Islet.

Glassner, Jean-Jacques 2004. Mesopotamian Chronicles. (Writings from the Ancient World 19) Atlanta: SBL Press.

Grayson, Kirk 1991. Assyrian Rulers of the Early First Millennium BC I (1114-859 BC). (Royal Inscriptions of Mesopotamia Assyrian Periods 2) Toronto: Toronto University Press.

Grayson, Kirk 1996. Assyrian Rulers of the Early First Millennium BC II (858-745 BC). (Royal Inscriptions of Mesopotamia Assyrian Periods 3) Toronto: Toronto University Press.

Grayson, Kirk \& Jamie Novotny 2012. The Royal Inscriptions of Sennacherib, King of Assyria (704-681 BC), I. (The Royal Inscriptions of the Neo-Assyrian Period 3(1)) Winona Lake, IN: Eisenbrauns.

Grayson, Kirk \& Jamie Novotny 2014. The Royal Inscriptions of Sennacherib, King of Assyria (704-681 BC), II. (The Royal Inscriptions of the Neo-Assyrian Period 3(2)) Winona Lake, IN: Eisenbrauns.

Jursa, Michael 2005. Neo-Babylonian Legal and Administrative Documents. (Guides to the Mesopotamian Textual Record 1) Münster: Ugarit.

Jursa, Michael 2006. Neubabylonische Briefe. In: B. JANOwski \& G. Wilhem (eds), Texte aus der Umwelt des Alten Testaments (Neue Folge 3): 158-172. Gütersloh: Gütersloher Verlagshaus. 
Jursa, Michael 2007. Die Söhne Kudurrus und die Herkunft der neubabylonischen Dynastie. Revue d'assyriologie et d'archéologie orientale 101: 125-136.

Karlsson, Mattias 2016. Relations of Power in Early Neo-Assyrian State Ideology. (Studies in Ancient Near Eastern Records 10) Boston: De Gruyter.

Karlsson, Mattias 2017. Alterity in Ancient Assyrian Propaganda. (State Archives of Assyria Studies 26) Helsinki: The Neo-Assyrian Text Corpus Project.

Leichty, Erle 2011. The Royal Inscriptions of Esarhaddon, King of Assyria (680-669 BC). (The Royal Inscriptions of the Neo-Assyrian Period 4) Winona Lake, IN: Eisenbrauns.

Liverani, Erle 1979. The Ideology of the Assyrian Empire. In: M. LARsen (ed.), Power and Propaganda: A Symposium on Ancient Empire (Mesopotamia 7): 297-317. Copenhagen: Akademisk Forlag.

LuUkKo, Mikko 2012. The Correspondence of Tiglath-pileser III and Sargon II from Calah/Nimrud. (State Archives of Assyria 19) Helsinki: The Neo-Assyrian Text Corpus Project.

McEwan, Gilbert J.P. 1983. Distribution of Meat in Eanna. Iraq 45: 187-198.

MACGINNIS, John 2010. Mobilisation and Militarisation in the Neo-Babylonian Empire. In: J. VIDAL (ed.), Studies on War in the Ancient Near East: Collected Essays on Military History (Alter Orient und Altes Testament 372): 153-163. Münster: Ugarit.

MacGinnis, John 2012. Population and Identity in the Assyrian Empire. In: Ö. Cetrez et al. (eds), The Assyrian Heritage: Threads of Continuity and Influence (Acta Universitatis Upsaliensis, Studies in Religion and Society 7): 131-153. Uppsala: Uppsala Universitet.

Machinist, Peter 1993. Assyrians on Assyria in the First Millennium BC. In: K.A. RaAflaub \& E. Müller-Luckner (eds), Anfänge politischen Denkens in der Antike: Die nahöstlichen Kulturen und die Griechen (Schriften des Historischen Kollegs: Koloquien 24): 77-104. Munich: R. Oldenberg.

Nielsen, John 2010. Three Early Neo-Babylonian Tablets Belonging to Bēl-ētị of the Mișirāya Kin Group. Journal of Cuneiform Studies 62: 95-104.

Nielsen, John 2018. Cultural Encounters and Identity Formation among the Urban Elite in Early Neo-Babylonian Society. In: T. Hertel et al. (eds), Cultural Encounters in Near Eastern History (CNI Publications 44): 91-117. Copenhagen: Museum Tusculanum Press.

Nielsen, John \& Caroline WaerzegGers 2016. Interactions between Temple, King and Local Elites: The hanšs Land Schemes in Babylonia (8th-6th Centuries BC). In: J. Moreno García (ed.), Dynamics of Production in the Ancient Near East 1300-500 BC: 331-344. Oxford: Oxbow Books.

Parpola, Simo 2004. National and Ethnic Identity in the Neo-Assyrian Empire and Assyrian Identity in Post-Empire Times. Journal of Assyrian Academic Studies 18(2): 5-22.

Paulus, Susanne 2014. Die babylonischen Kudurru-Inschriften von der kassitischen bis zur frühneubabylonischen Zeit. (Alter Orient und Altes Testament 51) Münster: Ugarit.

Radner, Karen 2014. The Neo-Assyrian Empire. In: M. GeHLER \& R. Rollinger (eds), Imperien und Reiche in der Weltgeschichte: Epochenübergreifende und globalhistorische Vergleiche: 101-119. Wiesbaden: Harrassowitz.

RADNer, Karen 2015. Royal Pen Pals: The Kings of Assyria in Correspondence with Officials, Clients and Total Strangers (8th and 7th Centuries BC). In: S. ProchÁzKa, L. ReInfandt \& S. Tost (eds), Official Epistolography and the Language(s) of Power (Papyrologica Vindobonensia 8): 61-72. Vienna: Österreichischen Akadamie der Wissenschaften.

ReYnolds, Frances 2003. The Babylonian Correspondence of Esarhaddon. (State Archives of Assyria 18) Helsinki: Helsinki University Press.

Rosenzweig, Melissa 2016. Cultivating Subjects in the Neo-Assyrian Empire. Journal of Social Archaeology 16: 307-334.

Seymour, Michael 2017. Neighbors through Imperial Eyes: Depicting Babylonia in the Assyrian Campaign Reliefs. Journal of Near Eastern History 4: 129-162.

Spar, Ira \& Eva Von Dassow 2001. Private Archive Texts from the First Millennium BC. (Cuneiform Texts in the Metropolitan Museum of Art 3) NY: The Metropolitan Museum of Art.

TADMOR, Hayim \& Shigeo YAMAda 2011. The Royal Inscriptions of Tiglath-pileser III (744-727 BC) and Shalmaneser V (726-722 BC), Kings of Assyria. (The Royal Inscriptions of the Neo-Assyrian Period 1) Winona Lake, IN: Eisenbrauns.

ZADOK, Ran 2017. The Account of Nabû-šuma-iškun Revisited. Altorientalische Forschungen 44: 261-267. 